\title{
Suitability evaluation of magnesium substituted biphasic calcium phosphates prepared by coprecipitation method
}

\author{
Hyoung-Sin Lee, Tae-Wan Kim, Dong-Hyun Kim, Hong-Chae Park and Seog-Young Yoon ${ }^{\dagger}$ \\ School of Materials Science Engineering, Pusan National University, Busan 609-735, Korea
}

(Received September 28, 2010)

(Revised October 8, 2010)

(Accepted October 11, 2010)

\begin{abstract}
Magnesium-substituted BCP (biphasic calcium phosphate) powders were prepared by incorporating small amounts of magnesium into the structure of different hydroxyapatite (HAp)/ $\beta$-tricalcium phosphate $(\beta$-TCP) ratios through coprecipitation method. A series of magnesium substitutions ranging from $0,0.5$, and $1.0 \mathrm{wt} \%$, which are comparable to the measured magnesium contents, were performed. The obtained powders were characterized by the following analytical techniques: X-ray diffraction analysis (XRD), Thermo Gravimetric Analyzer (TGA) and Fourier transform infrared spectroscopy (FT-IR). The results have shown that substitution of magnesium in the calcium-deficient apatites resulted in the formation of biphasic mixtures of different HAP $/ \beta$-TCP ratios after heating above $1000^{\circ} \mathrm{C}$. The $1.0 \mathrm{wt} \% \mathrm{magnesium}-$ substituted-BCP were soaked in Hank's solutions after 2 weeks to observe the morphology of the biocement, especially needle-like hydroxyapatite crystals and to estimate the length and diameter of nanoneedle crystals.
\end{abstract}

Key words Magnesium, Biphasic calcium phosphate, Hydroxyapatite, $\beta$-Tricalcium phosphate

\section{공침법을 이용한 마그네슘이 첨가된 biphasic calcium phosphate의 적합성 평가}

이형신, 김태완, 김동현, 박홍채, 윤석영

부산대학교 재료공학부, 부산, 609-735

(2010년 9월 28일 접수)

(2010년 10월 8일 심사완료)

(2010년 10월 11일 게재확정)

요 약 $\mathrm{Mg}-\mathrm{BCP}(\mathrm{Mg}$ Substituted $\mathrm{BCP})$ 를 제조하기 위하여 $\mathrm{Ca}\left(\mathrm{NO}_{3}\right)_{2} \cdot 4 \mathrm{H}_{2} \mathrm{O}(\mathrm{Katayama}$ chemical, Japan $)$ 과 $\left(\mathrm{NH}_{4}\right)_{2} \cdot \mathrm{HPO}_{4}$ (Junsei chemical, Japan), $\mathrm{Mg}\left(\mathrm{NO}_{3}\right)_{2} \cdot 6 \mathrm{H}_{2} \mathrm{O}$ (Junsei chemical, Japan)를 출발물질로 공침법(co-precipitation process)을 이용하여 합성하였다. 제조된 분말의 마그네슘의 첨가에 따른 분말의 분광학적 특성은 FT-IR(MAGNA-IR 560, Nicolet)을 통하여 분 석하였으며, SEM(S-4200, Hitachi)을 통하여 미세구조를 분석하였다. XRD 회절피크의 면적적분강도를 Integral Analysis (Rigaku, Japan)를 이용하여 HAp와 $\beta$-TCP의 비율을 확인하였다. $1.0 \mathrm{wt} \%$ 마그네슘이 첨가된 $\mathrm{BCP}$ 샘플의 경우 $\mathrm{Hank}$ 's solution에서의 2주 침적 후 표면에 침상의 HAp로 추정되는 결정이 성장하였다. 이러한 미세구조의 변화는 생활성을 가지 는 마그네슘의 첨가가 $\mathrm{BCP}$ 조직 내에서 표면의 활성을 증가시켜 결정의 성장을 촉진시킨 것으로 판단된다.

\section{1. 서 론}

최근 뼈의 결함 및 손상을 복원하기 위해서 인산칼슘 계열의 세라믹 재료들이 많은 주목을 받고 있다. 이들 인 산칼슘계 세라믹 재료 중 수산화인회석(Hydrowyapatite; HAp)과 $\beta$-삼인산칼슘(Tricalcium phosphate; $\beta$-TCP)은

Corresponding author

Tel: $+82-51-510-2487$

Fax: $+82-51-512-0528$

E-mail: syy3@pusan.ac.kr
생체적합성과 인체 골조직과의 화학적, 물리적인 유사성 으로 인하여 많은 연구가 이루어져 왔다[1-5]. 하지만 치 밀한 HAp는 생체 내에서 용해율이 낮아 숙주 결합 조 직 내에서 면역반응 없는 이물질로서 작용하여 신생골 형성을 위한 지지체로 기능을 하지 못하고 $[2,3,6], \beta-$ $\mathrm{TCP}$ 는 체액과 여러 용액에서 쉽게 흡수되어 골성장을 위한 골격을 예견성 있게 제공할 수 없어, 순수한 HAp 나 $\beta-\mathrm{TCP}$ 의 사용은 임상적으로 한계가 있다고 보고되고 있다 $[7,8]$. 따라서 $\mathrm{HAp}$ 의 안정성과 $\beta-\mathrm{TCP}$ 의 높은 용해 율을 적절히 혼합하여 골전도성은 유지하면서 재료의 흡 
수성을 조절한 이상인삼칼슘(Biphasic Calcium Phosphate; $\mathrm{BCP}$ )이 골이식 재료로서 장점을 지닐 수 있는 것으로 제시되었다. $\mathrm{BCP}$ 는 $\mathrm{HAp} / \beta-\mathrm{TCP}$ 의 비율을 조절하여 재 료의 생체활성이나 흡수성을 조절할 수 있어 현재 치과 나 정형외과 영역에서 임상적으로 성공적으로 이용되고 있다[9]. 생체 내에서 최적의 골전도성을 나타내기 위한 $\mathrm{HAp} / \beta-\mathrm{TCP}$ 의 비율은 명확히 제시되어 있지 않으나 약 $60: 40$ 의 $\mathrm{HAp} / \beta-\mathrm{TCP}$ 의 비율이 적절한 것으로 제시되었 다 $[10,11]$. 특히 최근에는 마그네슘이 치환된 아파타이 트 상의 무기화 처리 영향과 $\mathrm{HAp}$ 내에서의 결정 형성 과 성장이 주요한 이슈가 되고 있다[12,13]. HAp 격자 구조는 다양한 원소가 쉽게 치환 될 수 있는 구조를 가 지고 있다. 이러한 경우 분말의 결정성, 입자의 형상, 격 자의 길이, 열적성질이 변화하게 된다. 이러한 치환 인자 로는 양이온 $\left(\mathrm{Mg}^{2+}, \mathrm{Zn}^{2+}, \mathrm{Sr}^{2+}\right)$ 과 음이온 $\left(\mathrm{SiO}_{4}^{4-}, \mathrm{F}^{-}, \mathrm{CO}_{3}^{2-}\right)$ 이 주로 이용된다. 양이온 치환 인자 중 인체 내에 4 번 째로 많은 양이온인 마그네슘 $(0.44 \sim 1.23 \mathrm{wt} \%)$ 이 가장 널리 연구되고 있다[14, 15]. 게다가 골 내에 마그네슘 이 결핍될 경우 모든 단계의 뼈의 신진대사와 골아세 포의 골성장 및 활동성을 감소시키고, 골의 강도를 약 화시킨다[16]. 이에 calcium deficient HAp[d-HAP, $\mathrm{Ca}_{10-\mathrm{x}}\left(\mathrm{HPO}_{4}\right)_{\mathrm{x}}\left(\mathrm{PO}_{4}\right)_{6-\mathrm{x}}(\mathrm{OH})_{2-\mathrm{x}} ; 0=\mathrm{x}=1$ ] 격자 내에 마 그네슘을 치환시키면 $\mathrm{Mg}^{2+}$ 가 격자 내에서 아파타이트의 결정성을 감소시키고 열적안정성과 $\beta$ - TCP 형성에 영향 을 주어 $\mathrm{Ca} / \mathrm{P}$ 가 1.5 와 1.67 범위의 다양한 $\mathrm{BCP}$ 를 형성 하게 한다[17, 18].

$$
\begin{aligned}
& \mathrm{Ca}_{10-\mathrm{x}}\left(\mathrm{HPO}_{4}\right)_{\mathrm{x}}\left(\mathrm{PO}_{4}\right)_{6-\mathrm{x}}(\mathrm{OH})_{2-\mathrm{x}} \\
& \quad \rightarrow(1-\mathrm{x}) \mathrm{Ca}_{10}\left(\mathrm{PO}_{4}\right)_{6}(\mathrm{OH})_{2} \\
& \quad+3 \mathrm{xCa}_{3}\left(\mathrm{PO}_{4}\right)_{2}+(\mathrm{OH})_{2-\mathrm{x}}+\mathrm{xH}_{2} \mathrm{O}
\end{aligned}
$$

그러나 마그네슘이 치환된 $\mathrm{BCP}$ 를 제작할 경우 정량적 으로 정확히 혼재된 구조를 만들기 어렵다. $\mathrm{Mg}^{2+}$ 치환 되는 양을 조절하여서 결정성, 용해도, 입자의 형상, 나 노 입자 합성에 결과적으로 사용 할 수 있다[9].

본 연구에서는 공침법을 이용하여 일반적으로 생체 내에서 골전도성이 우수한 비율로 알려진 HAp/ $\beta$-TCP 의 비율이 $60: 40$ 인 $\mathrm{BCP}$ 분말을 합성하고 뼈의 신진대 사와 골아세포의 골성장 및 활동성을 증가시키는 마그 네슘이 $0.5 \mathrm{wt} \%, 1.0 \mathrm{wt} \%$ 치환된 $\mathrm{BCP}$ 분말을 합성하 였다. $\mathrm{X}$-선 회절분석을 통하여 공침물의 결정성을 동정 하고, $1000^{\circ} \mathrm{C}$ 하소 후 $\mathrm{BCP}$ 의 $\mathrm{Ca} / \mathrm{P}$ 몰분율을 $\mathrm{X}$-선 회 절분석을 이용하여 적분강도 값을 구한 후 비교 분석하 였다. 또한 마그네슘 첨가량에 따른 결정성, 열적 특성, 분광학적 특성, 미세구조를 관찰하였다. 생활성 마그네 슘의 첨가에 따른 생체유사 체액에서의 분해 및 생성 거동을 Hank's solution에 침적 후 그 변화를 관찰하 였다.

\section{2. 실험방법}

$\mathrm{Mg}-\mathrm{BCP}(\mathrm{Mg}$ Substituted $\mathrm{BCP})$ 를 제조하기 위하여 $\mathrm{Ca}\left(\mathrm{NO}_{3}\right)_{2} \cdot 4 \mathrm{H}_{2} \mathrm{O}$ (Katayama chemical, Japan)과 $\left(\mathrm{NH}_{4}\right)_{2}$. $\mathrm{HPO}_{4}$ (Junsei chemical, Japan), $\mathrm{Mg}\left(\mathrm{NO}_{3}\right)_{2} \cdot 6 \mathrm{H}_{2} \mathrm{O}$ (Junsei chemical, Japan)를 출발물질로 공침법(co-precipitation process)을 이용하여 합성하였다. $\mathrm{BCP}(\mathrm{HAp}: \beta-\mathrm{TCP}=$ $60: 40)$ 의 $\mathrm{Ca} / \mathrm{P}$ 몰 비율인 1.602 를 유지하기 위하여 $(\mathrm{Ca}+\mathrm{Mg}) / \mathrm{P}$ 를 1.602 로 하여 마그네슘을 $0.5 \mathrm{wt} \%, 1.0 \mathrm{wt} \%$ 치환하였다. 이를 위해서 $\mathrm{Ca}\left(\mathrm{NO}_{3}\right)_{2} \cdot 4 \mathrm{H}_{2} \mathrm{O}$ 과 $\left(\mathrm{NH}_{4}\right)_{2} \mathrm{HPO}_{4}$, $\mathrm{Mg}\left(\mathrm{NO}_{3}\right)_{2} \cdot 6 \mathrm{H}_{2} \mathrm{O}$ 를 정량으로 각각의 수용액을 제조하였 다. $300 \mathrm{~m}$ l의 탈 이온 증류수(distilled water)에 $\left(\mathrm{NH}_{4}\right)_{3}$ $\mathrm{HPO}_{4}$ 를 용해시킨 후 $\mathrm{NH}_{3}$ 를 적가하여 $\mathrm{pH} 11 \pm 0.1$ 로 조 절하였으며, $\mathrm{Ca}\left(\mathrm{NO}_{3}\right)_{2} \cdot 4 \mathrm{H}_{2} \mathrm{O}$ 와 $\mathrm{Mg}\left(\mathrm{NO}_{3}\right)_{2} \cdot 6 \mathrm{H}_{2} \mathrm{O}$ 를 피펫 을 통하여 적가하여 혼합교반 시켰다. 이때 혼합 시 변 화하는 $\mathrm{pH}$ 를 $\mathrm{NH}_{3}$ 를 적가하여 $\mathrm{pH} \quad 11 \pm 0.1$ 로 유지시켜 공침시켰다. 제조된 공침액을 2 시간 교반 후 상온에서 24시간 동안 시효처리 시켰다. 현탁액에서 공침물을 분 리하기 위하여 여과한 후 미반응 불순물을 제거하기 위 하여 증류수로 수차례 수세하고 공침물을 건조하기 위하 여 진공건조기에서 $80^{\circ} \mathrm{C}$ 로 고정하여 12 시간 건조하였다. 건조된 분말을 400 mash 체가름 하였다.

생성된 분말의 열처리 전 공침물 상태의 결정성을 알 아보기 위하여 XRD(D/max-IIA, Rigaku)를 사용하여 생성물의 상 분석을 행하고, 마그네슘 첨가에 따른 열적 거동을 파악하기 위해 TGA(DTG-60, Shimadzu) 이용 하여 열분석 하였다. $\mathrm{Mg}-\mathrm{BCP}$ 분말을 제조하기 위하여 공침 후 건조된 분말을 $1000^{\circ} \mathrm{C}\left(\right.$ 승온 속도 $\left.1^{\circ} \mathrm{C} / \mathrm{min}\right)$ 에 2 시간 열처리하여 제조하였다. 제조된 분말의 마그네슘 첨가에 따른 분말의 분광학적 특성은 FT-IR(MAGNAIR 560, Nicolet)을 통하여 분석하였으며, SEM(S-4200, Hitachi)을 통하여 미세구조를 분석하였다. XRD 회절피 크의 면적적분강도를 Integral Analysis(Rigaku, Japan) 를 이용하여 $\mathrm{HAp}$ 와 $\beta$-TCP의 비율을 확인하였다. 마그 네슘 첨가에 따른 생체활성 평가를 위하여 공침 후 건조 된 분말을 $\Phi ; 10 \mathrm{~mm} \times \mathrm{h} ; 10 \mathrm{~mm}$ 의 펠렛으로 제조하여 $1000^{\circ} \mathrm{C}$ (승온 속도 $1 / \mathrm{min}$ )에 2시간 열처리한 후 Hank's solution에 2주간 침적 후 표면의 미세구조를 $\mathrm{SEM}$ 을 통 하여 관찰하였다.

\section{3. 결과 및 고찰}

$\mathrm{BCP}(\mathrm{HAp}: \beta-\mathrm{TCP}=60: 40)$ 의 $\mathrm{Ca} / \mathrm{P}$ 몰 비율인 1.602 를 유지하기 위하여 공침시킨 공침물을 건조 후 측정한 $\mathrm{XRD}$ 패턴을 Fig. 1에 나타내었다. 마그네슘을 첨가하지 않은 $\mathrm{BCP}$ 분말과 $0.5 \mathrm{wt} \%, 1.0 \mathrm{wt} \%$ 를 첨가한 공침 분 


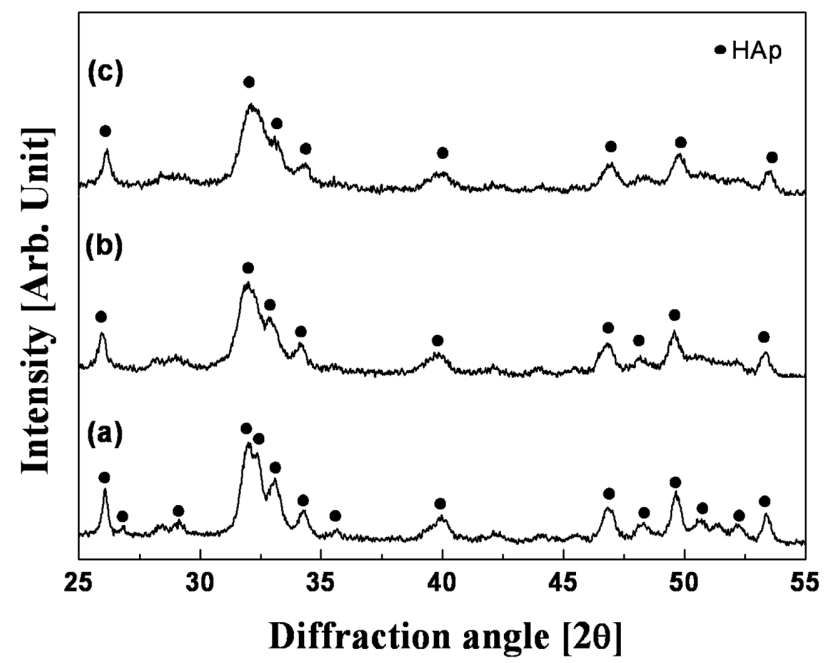

Fig. 1. XRD patterns of coprecipitate powders; (a) BCP, (b) $0.5 \mathrm{wt} \% \mathrm{Mg}-\mathrm{BCP}$, (c) $1.0 \mathrm{wt} \% \mathrm{Mg}-\mathrm{BCP}$.

말 모두에서 $\mathrm{HAp}$ 회절 패턴을 나타내었다. 그러나 마그 네슘이 첨가된 경우에 첨가되지 않은 경우에 비하여 회 절 peak가 완만해지고 회절 강도가 감소하는 경향이 나 타났다. 이는 공침 반응을 통하여 공침물 내에서 $\mathrm{Ca}^{2+}$ 가 $\mathrm{Mg}^{2+}$ 로 치환되어 마그네슘의 농도가 증가함에 따라 칼 슘 결손이 일어나고, 공침분말의 결정성이 감소하여, 회 절 peak가 완만해진 것으로 판단되어 진다. 그러나 마그 네슘의 치환에 따른 XRD 회절패턴에서는 $\mathrm{HAp}$ 결정상 외에 다른 결정상은 나타나지 않았다. 이는 공침법에 의 한 $\mathrm{HAp}$ 합성의 경우 공침분말의 $\mathrm{Ca} / \mathrm{P}$ 몰 비율이 1.67 보다 적어도 얻어지는 공침분말은 $\mathrm{HAp}$ 회절 패턴이 나 타난다는 앞선 연구결과와도 일치한다[20].

마그네슘 첨가에 따른 공침반응물의 열적 변화를 알아 보기 위하여 산화분위기에서 온도변화에 따른 중량 변화

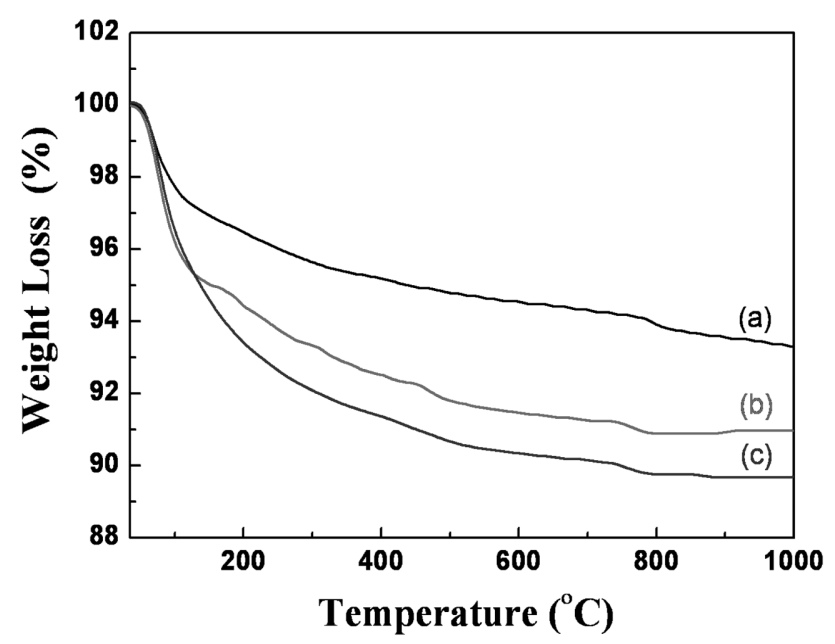

Fig. 2. TGA curve of coprecipitate powders; (a) BCP, (b) $0.5 \mathrm{wt} \% \mathrm{Mg}-\mathrm{BCP}$, (c) $1.0 \mathrm{wt} \% \mathrm{Mg}-\mathrm{BCP}$.
를 TGA(Thermo Gravimetric Analyzer)를 이용하여 관 찰한 결과를 Fig. 2에 나타내었다. 상온에서 $1000^{\circ} \mathrm{C}$ 까지 $10^{\circ} \mathrm{C} / \mathrm{min}$ 의 속도로 승온하면서 측정한 결과 상온에서 $250^{\circ} \mathrm{C}$ 까지는 4 7\% 내외의 중량변화가 나타난다. 이는 공침 분말의 표면에 흡착된 수분의 증발로 여겨지며, 마 그네슘을 첨가한 경우 첨가하지 않은 분말에 비하여 그 중량 변화는 두드러지게 나타났다. $600 \sim 800^{\circ} \mathrm{C}$ 온도구간 에서의 중량변화는 공침분말의 열에 의한 구조변화를 동 반하여 $\mathrm{OH}^{-}$결합이 감소한 결과로 여겨지며, 이러한 구 조변화는 아래의 식(2)로 나타낼 수 있다.

$$
\begin{aligned}
\mathrm{Ca}_{9} \mathrm{Mg} & \left(\mathrm{HPO}_{4}\right)\left(\mathrm{PO}_{4}\right)(\mathrm{OH}) \\
& \rightarrow 3\left(\mathrm{Ca}_{3-(\mathrm{x} / 3)} \mathrm{Mg}_{/ 3}\right)\left(\mathrm{PO}_{4}\right)_{2}+\mathrm{H}_{2} \mathrm{O}
\end{aligned}
$$

Fig. 3은 공침분말을 $1000^{\circ} \mathrm{C}$ 열처리 한 후 생성된 분 말의 XRD 회절 패턴을 나타낸 것이다. 열처리 결과 마 그네슘 첨가 유무에 관계없이 본 연구에서 얻고자하는 $\mathrm{HAp}: \beta-\mathrm{TCP}=60: 40 \mathrm{BCP}$ 분말의 회절 패턴을 나타내 었다. 20와 d-spaceing 값을 보면 모든 샘플에서 JCPDS $\# 74-0566$ 의 HAp의 (211)면과 JCPDS \#09-0169의 $\beta$ $\mathrm{TCP}$ 의 (0210)면이 나타남을 관찰할 수 있었다. 또한 마 그네슘의 첨가에 따라 $\mathrm{BCP}$ 회절 패턴의 peak 강도가 감소하는 경향이 나타났다. 이는 Fig. 1의 마그네슘이 첨가됨에 따라 $\mathrm{Ca}^{2+}$ 가 $\mathrm{Mg}^{2+}$ 로 치환되어 결정성이 감소 하는 경향과 일치한다. 또한 공침분말의 열분석 결과 $600 \sim 800^{\circ} \mathrm{C}$ 부근의 중량변화가 구조변화를 동반하고 $\mathrm{Mg}^{2+}$ 가 $\mathrm{HAp}$ 격자 내에 $\mathrm{Ca}^{2+}$ 를 대체하여 치환되면 $\mathrm{HAp}$ 의 결정성이 감소하는 반면 $\beta-\mathrm{TCP}$ 가 열적으로 안정화되 어 $\alpha-\mathrm{TCP}$ 의 생성 온도가 $1125^{\circ} \mathrm{C}$ 이상으로 증가하게 되 어 $1000^{\circ} \mathrm{C}$ 열처리를 통하여 본 연구에서 얻고자 하는 $\mathrm{HAp}: \beta-\mathrm{TCP}=60: 40$ 의 분말을 얻을 수 있었다[21].

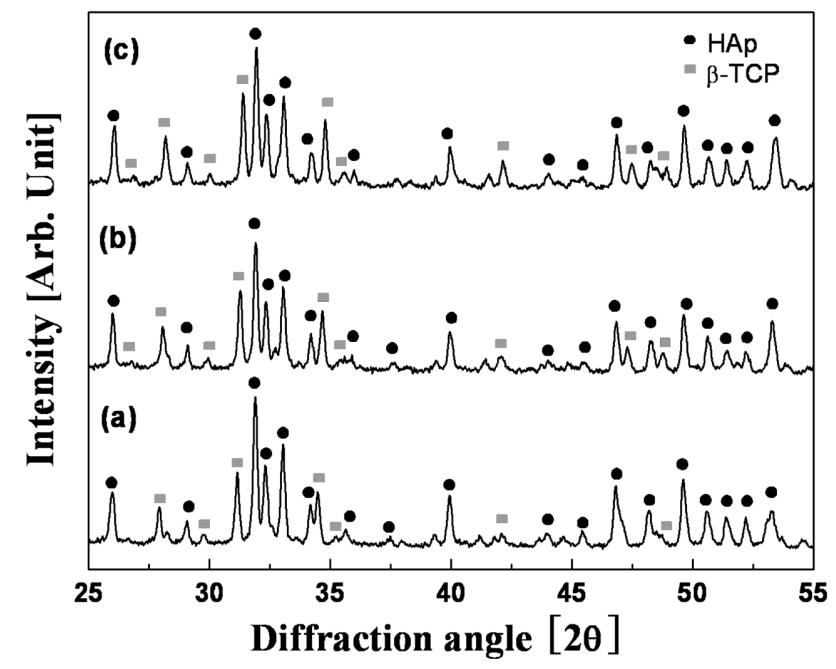

Fig. 3. XRD patterns of as-calcined powders; (a) BCP, (b) $0.5 \mathrm{wt} \% \mathrm{Mg}-\mathrm{BCP}$, (c) $1.0 \mathrm{wt} \% \mathrm{Mg}-\mathrm{BCP}$. 


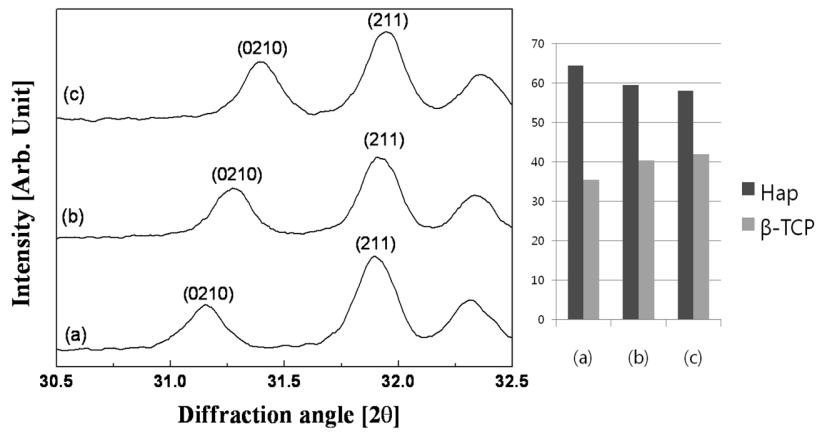

Fig. 4. Integral intensity of as-calcined powders calculated from XRD patterns; (a) BCP, (b) $0.5 \mathrm{wt} \% \mathrm{Mg}-\mathrm{BCP}$, (c) $1.0 \mathrm{wt} \%$ $\mathrm{Mg}-\mathrm{BCP}$.

Fig. 4는 Fig. 3의 XRD 회절 패턴 결과를 확대하여 측정을 통해 얻어진 결과를 토대로 계산된 적분 강도 값 및 화학적 분석(정량분석)과 XRD 결과에 의한 $\mathrm{HAp}: \beta-$ $\mathrm{TCP}$ 비율의 관계를 나타낸 그림이다. 적분 강도 값은 Rigaku integral analysis 프로그램을 통해 분석하였다. 이때 측정범위는 $\beta$-TCP 상의 경우 $2 \theta$ 범위 중 30.7 $31.3^{\circ}$ 에서 계산하였고, $\mathrm{HAp}$ 상의 경우 $31.7 \sim 32.3^{\circ}$ 에서 계산하였다. 적분 강도 값을 (Eq. 3)에 대입하여 부피 분율을 나타낸 다음 XRD 측정값에 의한 $\mathrm{HAp}: \beta-\mathrm{TCP}$ 비율을 구하였다.

$$
\mathrm{Vf}_{\beta-\mathrm{TCP}}=\frac{\mathrm{I}_{\beta-\mathrm{TCP}}}{\mathrm{I}_{\beta-\mathrm{TCP}}+\mathrm{I}_{\mathrm{HAP}}}
$$

$\mathrm{HAp}: \beta-\mathrm{TCP}$ 비율을 계산한 결과 마그네슘이 첨가됨에 따라 $\beta$-TCP 비율이 증가하는 것으로 나타났다. 이는 $\mathrm{Ca}^{2+}$ 에 $\mathrm{Mg}^{2+}$ 가 치환되면서 $\mathrm{HAp}$ 의 결정성을 떨어지고 상대적으로 $\beta-\mathrm{TCP}$ 의 결정성은 향상되는 결과에 기인한 것이다. 또한 $\mathrm{Mg}^{2+}$ 의 이온반경은 $0.85 \AA$ 으로 $\mathrm{Ca}^{2+}$ 의 이 온반경인 $1.14 \AA$ 에 비하여 작으므로 이온화 에너지에 의 한 결합력이 증가한다. 이로 인해 이온결합인 $\mathrm{Mg}^{2+}$ 양이 온과 $\mathrm{PO}_{4}^{3-}$ 음이온의 결합이 증가하여 $\mathrm{OH}^{-}$결합을 상대 적으로 배제하여 마그네슘의 첨가량이 증가할수록 $\beta$ $\mathrm{TCP}$ 의 비율이 증가하는 것으로 판단된다.

마그네슘 첨가에 따른 $\mathrm{BCP}$ 분말의 $1000^{\circ} \mathrm{C}$ 열처리 후

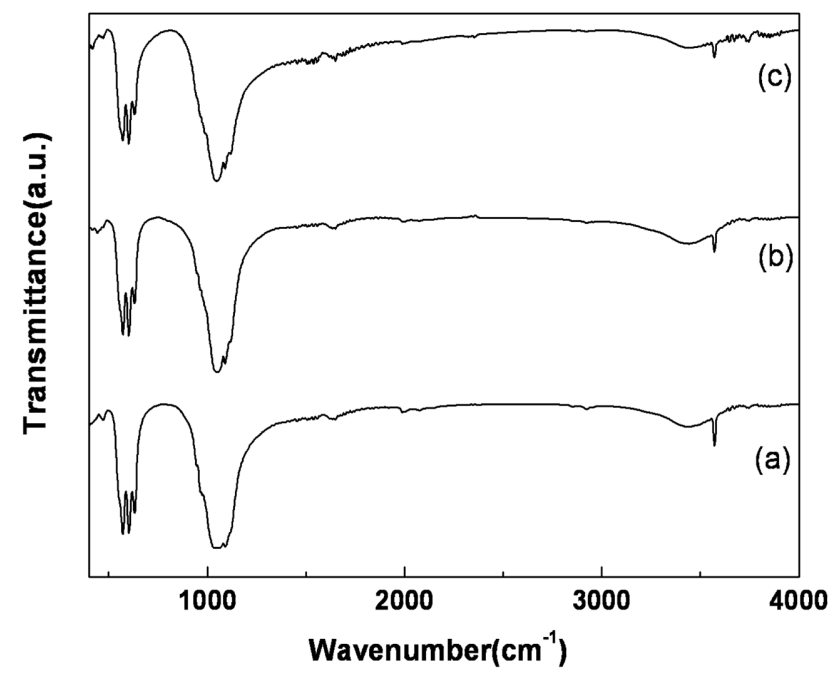

Fig. 6. FT-IR spectra of as-calcined powders; (a) BCP, (b) $0.5 \mathrm{wt} \% \mathrm{Mg}-\mathrm{BCP}$, (c) $1.0 \mathrm{wt} \% \mathrm{Mg}-\mathrm{BCP}$.

의 미세구조를 Fig. 5에 나타내었다. 마그네슘을 첨가하 지 않은 $\mathrm{BCP}$ 분말과 마그네슘이 $0.5 \mathrm{wt} \%, 1.0 \mathrm{wt} \%$ 첨 가된 $\mathrm{Mg}-\mathrm{BCP}$ 분말의 미세구조에는 큰 차이를 보이지 않는다. 그러나 열적으로 안정한 상인 $\beta-\mathrm{TCP}$ 의 비율이 증가함으로서 내부의 공극이 작아지는 경향을 관찰할 수 있었다.

공침분말의 $1000^{\circ} \mathrm{C}$ 열처리 후의 마그네슘 첨가에 따 른 분광학적 특성을 알아보기 위하여 FT-IR을 측정하여 Fig. 6에 나타내었다. 모든 샘플에서 $602 \mathrm{~cm}^{-1}, 567 \mathrm{~cm}^{-1}$ 인 $\mathrm{V}_{4} \mathrm{PO}_{4}^{-3}$ bend와 $504 \mathrm{~cm}^{-1}$ 인 $\mathrm{V}_{2} \mathrm{PO}_{4}^{-3}$ bend와 $3570 \mathrm{~cm}^{-1}$ 의 $\mathrm{OH}^{-}$stretching의 값의 감소를 통해 이를 확인할 수 있다. FT-IR 결과에서 마그네슘 첨가량이 증가할수록 $\mathrm{OH}$ 와 $\mathrm{PO}_{4}$ bend가 감소하는 경향을 나타내는데 이는 Fig. 1, Fig. 3의 XRD 결과와 Fig. 2의 TGA결과를 뒷받침하는 결과이다. 또한 $3300 ~ 3600 \mathrm{~cm}^{-1}$ 범위는 수 분의 흡수영역으로 마그네슘의 첨가량이 증가할수록 감 소하는 경향을 나타내는데 이는 마그네슘이 첨가됨에 따라 $\beta-\mathrm{TCP}$ 의 비율이 증가하여 나타나는 결과로 사료 된다.

생활성 마그네슘의 첨가에 따른 생체 유사체액에서의

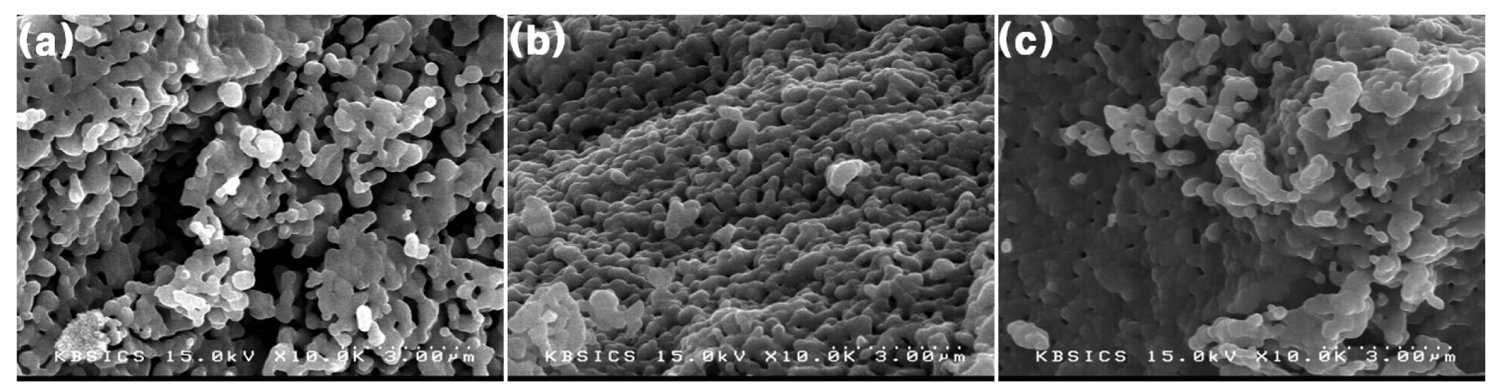

Fig. 5. SEM micrographs of as-calcined powders; (a) BCP, (b) $0.5 \mathrm{wt} \% \mathrm{Mg}-\mathrm{BCP}$, (c) $1.0 \mathrm{wt} \% \mathrm{Mg}-\mathrm{BCP}$. 


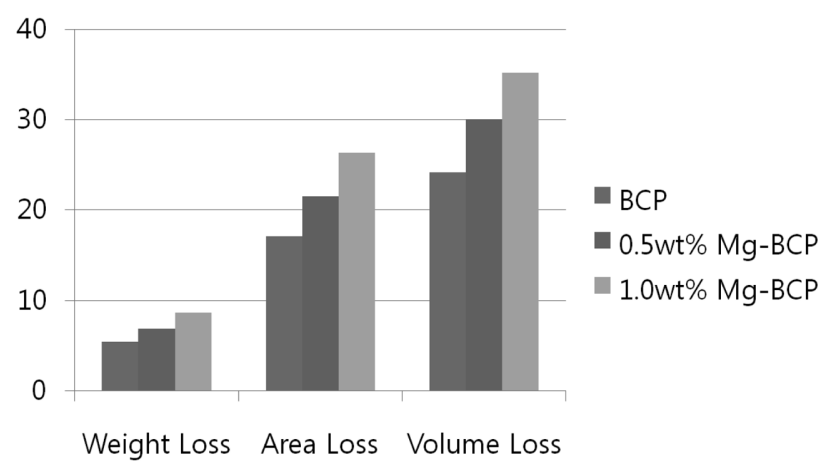

Fig. 7. Physical properties of $\mathrm{Mg}-\mathrm{BCP}$ pallets sintered at $1000^{\circ} \mathrm{C}$.

분해 및 생성 거동을 알아보기 위하여 공침분말을 펠렛 으로 제작하여 $1000^{\circ} \mathrm{C}$ 열처리 한 후 샘플의 수축률을 비교한 결과를 Fig. 7에 나타내었다. 마그네슘이 첨가되 지 않은 $\mathrm{BCP}$ 샘플과 비교하여 마그네슘이 첨가된 샘플 의 경우 열처리 후의 무게변화가 두드러지며, 면적 수축 률과 부피 수축률이 증가하는 경향을 나타내었다. 이는 Fig. 2의 결과에서와 같이 온도에 따른 중량변화가 마그 네슘의 첨가에 따라 증가하고 $\mathrm{HAp}$ 보다 열적으로 안정 한 $\beta$-TCP가 마그네슘의 치환으로 증가되었기 때문인 것 으로 사료된다.

Fig. 8은 생활성을 가지는 마그네슘의 첨가를 통하여 생체유사체액인 Hank's solution에서의 2주 침적 후 표 면의 미세조직 변화를 관찰한 것이다. 마그네슘을 첨가 하지 않은 $\mathrm{BCP}$ 샘플과 $0.5 \mathrm{wt} \%$ 의 마그네슘이 첨가된 $\mathrm{BCP}$ 샘플의 경우 Hank's solution에서의 2주 침적 후 특이한 변화가 관찰되지 않았으나, $1.0 \mathrm{wt} \%$ 의 마그네슘 이 첨가된 $\mathrm{BCP}$ 샘플의 경우 표면에 침상의 $\mathrm{HAp}$ 로 추 정되는 결정이 성장하였다. 이러한 미세구조의 변화는 생활성을 가지는 마그네슘의 첨가가 $\mathrm{BCP}$ 조직 내에서 표면의 활성을 증가시켜 결정의 성장을 촉진시킨 것으로 판단된다. 생체유사체액에서의 미세구조 발달에 영향을 미치는 마그네슘의 정량에 관한 연구는 추후 논의 되어 야 할 것으로 예상된다.

\section{4. 결 론}

본 연구에서는 HAp: $\beta-\mathrm{TCP}$ 의 비율을 $60: 40$ 의 마그네 슘이 첨가된 이상인삼칼슘(Biphasic Calcium Phosphate; $\mathrm{BCP}$ )을 공침법을 이용하여 합성하였다. $\mathrm{Ca}^{2+}$ 이온이 $\mathrm{Mg}^{2+}$ 이온으로 치환되어 $\mathrm{Mg}$ - $\mathrm{BCP}$ 가 얻어졌으며, $\mathrm{XRD}$ 결과에서 보듯이, 마그네슘의 첨가량이 증가함으로써 $2 \theta$, d-spacing 값이 이동되었다. 이러한 결과는 TGA, FT-IR 결과와도 일치한다. 마그네슘이 첨가된 $\mathrm{BCP}$ 의 경 우 마그네슘이 첨가됨에 따라 $\beta$ - TCP로의 상전이가 촉진 되어 정량의 $\mathrm{HAp}: \beta-\mathrm{TCP}$ 의 비율을 유지하기 어려운 단 점이 있다. 또한 펠렛 제작 후 샘플의 열처리를 통하여 수축률을 측정한 결과 마그네슘이 첨가된 경우 높은 수 축률을 나타내었다. Hank's solution 침적을 통하여 마그 네슘의 활성에 따른 표면의 미세구조의 변화를 관찰한 결과 $1.0 \mathrm{wt} \%$ 마그네슘이 첨가된 $\mathrm{BCP}$ 샘플의 표면에서 침상의 $\mathrm{HAp}$ 로 추정되는 결정이 성장하였다. 이러한 결 과로 $\mathrm{Mg}-\mathrm{BCP}$ 의 제조는 마그네슘의 생활성과 $\mathrm{HAp}$ 의 안정성 및 $\beta-\mathrm{TCP}$ 의 분해성으로 인하여 생체재료로서의 그 응용 가치가 충분하다고 사료된다.

\section{감사의 글}

본 연구는 교육과학기술부와 한국산업기술진흥원의 지 역혁신인력양성사업으로 수행된 연구결과입니다.

\section{참 고 문 헌}

[1] T. Han, F.A. Carranza Jr and E.B. Kenney, "Calcium phosphate ceramics in dentistry: a review of the literature", J. West Soc. Periodontol Periodontal Abstr. 32 (1984) 80.

[2] S.J. Froum, L. Kushner, I.W. Scopp and S.S. Stahl, "Human clinical and histologic responses to Durapatite implants in intraosseous lesions. Case reports", J Periodontol. 53 (1982) 719.

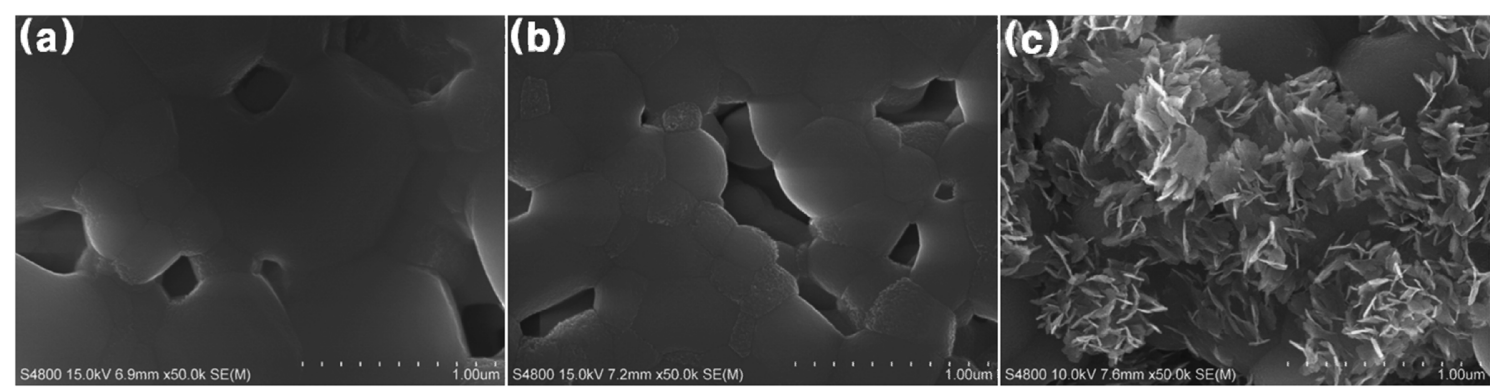

Fig. 8. SEM micrographs of the surface of the Mg-BCP pallets after soaking in Hank's solution for 2 weeks; (a) BCP, (b) 0.5 wt $\%$ $\mathrm{Mg}-\mathrm{BCP}$, (c) $1.0 \mathrm{wt} \% \mathrm{Mg}-\mathrm{BCP}$. 
[3 ] B.S. Moskow and A. Lubarr, "Histological assessment of human periodontal defeat after durapatite ceramic implant. Report of a case", J Periodontol. 54 (1983) 455.

[4] M.P. Levin, L. Getter, J. Adrian and D.E. Cutright, "Healing of periodontal defects with ceramic implants", J Clin Periodontol. 1 (1974) 197.

[ 5 ] R.A. Yukna, B.G. Harrison, R.F. Caudill, et al., "Evaluation of durapatite ceramic as an alloplastic implant in periodontal osseous defects. II. Twelve month reentry results", J Periodontol. 56 (1985) 540.

[6 ] R.F. Ellinger, E.B. Nery and K.L. Lynch, "Histological assessment of periodontal osseous defects following implantation of hydroxyapatite and biphasic calcium phosphate ceramics: a case report", Int J Periodontics Restorative Dent. 6 (1986) 22.

[7] M. Jarcho, "Calcium phosphate ceramics as hard tissue prosthetics", Clin Orthop Relat Res. 157 (1981) 259.

[ 8 ] D. Buser, B. Hoffmann, J.P. Bernard, et al., "Evaluation of filling materials in membrane-protected bone defects. A comparative histomorphometrib study in the mandible of miniature pigs", Clin Oral Implants Res. 9 (1998) 137.

[9] E.B. Nery, R.Z. LeGeros, K.L. Lynch and K. Lee, "Tissue response to biphasic calcium phosphate ceramic with different ratios of HA/beta TCP in periodontal osseous defects", Periodontol. 63 (1992) 729.

[10] R.Z. LeGeros, S. Lin, R. Rohanizadeh, D. Mijares and J.P. LeGeros, "Biphasic calcium phosphate bioceramics: preparation, properties and applications", J. Mater. Sci. Mater. Med. 14 (2003) 201.

[11] G. Daculsi, R.Z. LeGeros, M. Heughebaert and I. Barbieux, "Formation of carbonate-apatite crystals after implantation of calcium phosphate ceramics", Calcif Tissue Int. 46 (1990) 20.

[12] C. Ergun, T.J. Webster, R. Bizias and R.H. Doremus, "Hydroxylapatite with substituted magnesium, zinc, cadmium, and yttrium. I. Structure and microstructure". J.
Biomed. Mater. Res. 59 (2002) 305.

[13] A. Creedon, A. Flynm and A. Cashman, Br, "The effect of moderately and severely restricted dietary magnesium intakes on bone composition and bone metabolism in the rat", British Journal of Nutrition. 82 (1999) 63.

[14] K. Lilley, U. Gbureck, J. Knowles, D. Farrar and J. Barralet, "Cement from magnesium substituted hydroxyapatite", J. Mater. Sci. Mater. Med. 16 (2005) 455.

[15] W.L. Suchanek, K. Byrappa, P. Shuk, R.E. Riman, V.F. Janas and K.S. TenHuisen, "Preparation of magnesiumsubstituted hydroxyapatite powders by the mechanochemical-ydrothermal method", Biomaterials. 25 (2004) 4647.

[16] M. Percival, "Bone health \& osteoporosis", Appl. Nutr. Sci. Rep. 5(4) (1999) 1.

[17] O. Gauthier, J.M. Bouler, E. Aguado, P. Pilet and G. Daculsi, "Macroporous biphasic calcium phosphate ceramics: influence of macropore diameter and macroporosity percentage on bone ingrowth", Biomaterials. 19 (1998) 133.

[18] R.Z. LeGeros, "Calcium phosphates in oral biology and medicine, in: H.M. Myers (Ed.)", Monographs in Oral Science, Karger, Basel (1991) 31.

[19] K. Ishikawa, P. Ducheyne and S. Radin, "Determination of the $\mathrm{Ca} / \mathrm{P}$ ratio in calcium-deficient hydroxyapatite using X-ray diffraction analysis", J. Mater. Sci. Mater. Med. 4 (1993) 165.

[20] S.R. Kim, J.H. Lee, Y.T. Kim, D.H. Riu, S.J. Jung, Y.J. Lee, S.C. Chung and Y.H. Kim, "Synthesis of Si, Mg Substituted Hydroxyapatites and their Sintering Behaviors", Biomaterials 24 (2003) 1389.

[21] S. Kannan, I.A.F. Lemos, J.H.G. Rocha and J.M.F. Ferreira, "Synthesis and characterization of magnesium substituted biphasic mixtures of controlled hydroxyapatite/ $\beta$-tricalcium phosphate ratios", Journal of Solid State Chemistry 178 (2005) 3190. 